\title{
Species Delimitation and Host Specialization of Ceratocystis laricicola and $C$. polonica to Larch and Spruce
}

\author{
T. C. Harrington, Department of Plant Pathology, Iowa State University, Ames 50011; N. V. Pashenova, Labora- \\ tory of Microbiology, Sukachev Institute of Forestry, Krasnoyarsk, Russia; D. L. McNew and J. Steimel, Depart- \\ ment of Plant Pathology, Iowa State University; and M. Yu. Konstantinov, Laboratory of Microbiology, Sukachev \\ Institute of Forestry, Krasnoyarsk, Russia
}

\begin{abstract}
Harrington, T. C., Pashenova, N. V., McNew, D. L., Steimel, J., and Konstantinov, M. Y. 2002. Species delimitation and host specialization of Ceratocystis laricicola and C. polonica to larch and spruce. Plant Dis. 86:418-422.

Ceratocystis laricicola and C. polonica are fungal symbionts of bark beetle species of the genus Ips that attack species of Larix and Picea, respectively, across Eurasia. Earlier studies found that these fungal species were morphologically identical, had similar isozymes patterns, and had identical internal transcribed spacer (ITS) sequences of the rDNA operon. We analyzed 27 isolates from Europe, southwestern Siberia (Russia) and Japan, representing the known geographic ranges of the two species. Phylogenetic analysis of the DNA sequences of a portion of the MAT2 idiomorph showed these species to be distinct, with the Japanese isolates of C. laricicola having a sequence slightly different $(5 \mathrm{bp})$ from those of the Russian and European isolates of C. laricicola. Sexual compatibility tests showed full interfertility among isolates of $C$. polonica from Europe, Russia and Japan, but isolates of $C$. polonica were not fully interfertile with isolates of C. laricicola. A Russian and a European isolate of $C$. laricicola mated with each other but not with the Japanese isolates of $C$. laricicola. Mature $L$. sibirica and P. obovata were inoculated with isolates of $C$. laricicola and $C$. polonica from Europe, Russia, and Japan, and measurement of lesions in the inner bark/cambium region demonstrated strong host specialization. The data suggest that the two fungal species are very closely related and are distinguished primarily by their physiological specialization to the hosts of their bark beetle vectors.
\end{abstract}

Additional keywords: biological species, Ips cembrae, Ips typographus

Bark beetles (Coleoptera: Scolytidae) are among the most important killers of trees in the family Pinaceae, especially on Pinus, Picea and Larix (15). Bark beetles are intimately associated with a variety of fungi, most notably, members of the genus Ophiostoma and their associated anamorphic species of Leptographium (5-7). Although species of Ceratocystis sensu stricto are generally associated with other insects, there are three species of Ceratocystis associated with tree-killing bark beetles $(12,21)$. Two of these Ceratocystis species, C. laricicola Redfern \& Minter and $C$. polonica Siemaszko, are associated with closely related species of Ips, I. cembrae and I. polonica, which attack Larix and Picea species, respectively, across Eurasia, from northern Europe to Japan (12-14,16-18,22,23,25,26). When inoculated into healthy trees, these Ceratocystis species induce extensive lesions $(2,13,14$, $16,18,25,26)$, and it is thought that the

Corresponding author: T. C. Harrington

E-mail: tcharrin@iastate.edu

Accepted For Publication 30 November 2001.

Publication no. D-2002-0214-01R

(C) 2002 The American Phytopathological Society respective bark beetles kill their hosts through the actions of these plant pathogenic fungal species $(2,7,13,14,16,18$, 25,26). Of the fungi associated with tree killing bark beetles, these two species may be the most aggressive pathogens to trees (15), and thus, these species are important in the development of conceptual models of the interactions among fungi, bark beetles and their plant hosts.

It is questionable if $C$. laricicola and $C$. polonica are distinct species. Siemaszko (17) mistakenly connected a Leptographium anamorph to $C$. polonica, and because of this confusion, Redfern et al. (16) did not compare their new species, $C$. laricicola, to the earlier described $C$. polonica (20). Harrington and Wingfield (12) recognized the two fungal species as distinct, though no morphological feature appeared to separate them. Analyses of the internal transcribed spacer region (ITS) of the rDNA operon demonstrated no difference between the species (24), though there appeared to be some differences in the DNA sequence of a portion of the MAT-2 mating type idiomorph of the two species (22). Also, isolates of C. polonica had a unique electromorph for the isozyme diaphorase (11).

The two species also appear to have an interfertility barrier, but sexual compatibil- ity is difficult to test in the homothallic Ceratocystis species (9). Most Ceratocystis species are capable of unidirectional mating type switching, in which one of the mating types (MAT-2) is capable of selfing, producing progeny that are self-sterile (MAT-1) or self-fertile (MAT-2) in a 1:1 segregation pattern (8). The MAT-1 progeny is always self-sterile but can cross with MAT-2 strains, whereas MAT-2 progeny is usually self-fertile but can also cross with MAT-1 strains. Selfing in MAT-2 strains of Ceratocystis species occurs via a deletion of the MAT-2 idiomorph, which transforms the strain to the MAT-1 mating type (23). Normal mating apparently occurs between the switched (MAT-1) and unswitched (MAT-2) nuclei (8). Testers of MAT-1 strains are easily identified as self-sterile progeny derived from selfings. The MAT- 2 testers are more difficult to identify but can sometimes be found in self-sterile sectors of otherwise self-fertile MAT-2 strains. These MAT- 2 testers are generally only able to form perithecia and ascospores when paired with MAT-1 testers, though sometimes they can be induced to self when paired with either MAT-1 or MAT-2 strains (9). Using such MAT-2 mutants, pairings between $C$. polonica and $C$. laricicola were only partially interfertile (9).

Because of the importance of these respective bark beetle species and the fact that the Ceratocystis species are important plant-pathogenic symbionts, we made a detailed comparison of isolates of the two species from Europe, southwestern Siberia (south-central Russia), and Japan. We employed phylogenetic analysis of a portion of the MAT-2 idiomorph, conducted tests for sexual interfertility, and made morphological comparisons. Lastly, we inoculated mature larch and spruce trees to determine if the isolates were physiologically specialized to the respective tree hosts.

\section{MATERIALS AND METHODS}

Isolates. In all, 27 isolates of $C$. polonica and $C$. laricicola were examined. Most of the isolates studied are in the collection of the T. C. Harrington, (isolate numbers beginning with the letter $\mathrm{C}$ ), while some of the Siberian isolates are maintained in the collection of the N. V. Pashenova. Some of the isolates are also maintained in the Centraalbureau voor 
Schimmelcultures (CBS), the American Type Culture Collection (ATCC), or the Norwegian Forest Research Institute $($ NISK): $\mathrm{C} 181=\mathrm{CBS} 100207, \mathrm{C} 320=$ CBS 228.83, C322 = CBS 133.38, C731 = ATCC $62335=$ NISK 80-53-7, C746 = CBS 100208, C755 = CBS 100206, and C791 = CBS $100205=$ NISK 90-120-181. Collection information for most of the isolates can be found in Harrington and Wingfield (12), while the Russian isolates of C. laricicola and C. polonica were collected in 1994 to 1996 from galleries of Ips cembrae or I. typographus in Larix sibirica Ledeb. or Picea obovata Ledeb., respectively, in southern Siberia, near Krasnoyarsk, Russia.

MAT-2 Sequences. Isolates were grown in liquid culture with $20 \mathrm{~g} /$ liter malt extract and $10 \mathrm{~g} / \mathrm{liter}$ yeast extract for 10 to 14 days at room temperature (approximately $21^{\circ} \mathrm{C}$ ) before DNA extraction. Mycelium was harvested, and the DNA was extracted using the method described by DeScenzo and Harrington (3). The primers used for $C$. laricicola and $C$. polonica were LMAT2-F (5'-CGGAAAGACAGACACC AAGAC-3') and LMAT2-R (5'-GGTTGT AACGGTAGTGGGGATA-3') (22), except for the Japanese isolates of C. laricicola, which used LMAT2-F and the degenerate primer NeHMG-2 (1).

The $100 \mu \mathrm{l}$ polymerase chain reaction (PCR) reactions included $200 \mu \mathrm{M}$ of dNTPs, $0.5 \mu \mathrm{M}$ of the degenerate primers or $0.25 \mu \mathrm{M}$ of the specific primers, $4 \mathrm{mM}$ $\mathrm{MgCl}_{2}, 1 \times$ PCR buffer (supplied with the enzyme), 2.5 units Taq polymerase (Promega, Madison, WI), and 10 to $50 \mathrm{ng}$ of extracted DNA. The PCR products were generated using an initial denaturation of $60 \mathrm{~s}$ at $95^{\circ} \mathrm{C}$, followed by 35 cycles of $95^{\circ} \mathrm{C}$ for $35 \mathrm{~s}$, annealing at $60^{\circ} \mathrm{C}\left(52^{\circ} \mathrm{C}\right.$ for the Japanese $C$. laricicola isolates) for 60 $\mathrm{s}$, and elongation at $72^{\circ} \mathrm{C}$ for $60 \mathrm{~s}$. Amplified products of the expected size were purified using the Concert Rapid PCR Purification Kit (Invitrogen Corporation, Carlsbad, CA) for direct sequencing with the primers LMAT2-F and LMAT2-R at Iowa State University DNA Sequencing and Synthesis Facility using an ABI PRISM 377 DNA Sequencer (Applied Biosystems, Foster City, CA). The PCR products for the Japanese C. laricicola isolates were gel purified (Geneclean II kit, BIO 101Inc., Vista, CA) and cloned into pGEM-T easy vector (Promega Inc., Madison, WI). The plasmids were purified using the QIAprep Spin Miniprep plasmid DNA extraction kit (Qiagen Inc., Valencia, CA) and sequenced with the primers T7-2 and SP6.

The MAT-2 HMG box nucleotide sequences were manually aligned, with 10 characters from the intron region missing in the $C$. polonica and $C$. laricicola sequences when compared to the outgroup taxon $(C$. virescens). Including gaps, there were 197 characters in the analysis. Parsimony analysis (PAUP version 4.0b5, [19]) used the heuristic search option (optimality criterion $=$ maximum parsimony, gaps treated as a newstate or fifth character, simple taxon addition, with the branchswapping algorithm $=$ tree-bisection reconnection). Confidence levels were determined using 1,000 bootstrap replicates (4).

Interfertility. The MAT-2 isolates of these species are usually self-fertile, but we identified MAT-2 testers of $C$. laricicola and $C$. polonica that were no longer self-fertile, rarely produced perithecia and ascospores through selfing, or in the case of C1226-3, produced perithecia without necks. All but one of the MAT-2 isolates (C757) used in interfertility tests were proven to be MAT-2 by amplifying a portion of the MAT-2 idiomorph using the above described PCR primers. Self-sterile, MAT-1 progeny were selected from selfings of C178 of C. laricicola and C791 and C1226 of $C$. polonica. Self-sterile field isolates $\operatorname{lrc} 02 / 94, \mathrm{C} 745$, and C755 were presumed to be MAT-1.

Cultures were grown and pairings were conducted as described by Harrington and McNew (9). The MAT-1 testers were used as recipients (females) and the MAT-2 testers were donors (spermatizing strains or males). Recipient cultures were grown for 8 days on $1.5 \%$ malt extract with $2.0 \%$ agar (MEA) in 95-mm-diameter plastic petri dishes; an autoclaved 3-cm-long twig of Pinus strobus with bark removed was placed in the recipient plate before addition of molten MEA. Spermatizing cultures were grown on MYEA (2.0\% malt extract, $0.2 \%$ yeast extract, and $1.5 \%$ agar), which is more suited than MEA for conidium production. The spermatizing cultures were flooded with sterile, deionized water. Conidia, conidiophores, and mycelial fragments were loosened by lightly scraping with a spatula, and 1 or $2 \mathrm{ml}$ of this suspension was added to each recipient culture. The recipient plate was swirled slightly to disperse the inoculum. Plates were incubated at room temperature (20 to $23^{\circ} \mathrm{C}$ ) and lighting, and the recipient plates were inspected periodically for perithecia and ascospore production, which was generally evident within 2 weeks, but plates were observed periodically for up to 5 weeks. The MAT- 2 testers were also paired with themselves, but no perithecia were noted in these self-pairings, except that self-pairings of C1226-3 produced abundant perithecia without necks.

Single-ascospore progeny was recovered as described by Harrington and $\mathrm{McNew}$ $(8,9)$ after first dispersing the ascospores in a light oil (Isopar M). Germination of ascospores was assessed by streaking the dispersed ascospores across a MEA-coated microscope slide, incubating at room temperature for $24 \mathrm{~h}$, and examining the spores at $\times 400$

Morphology. Because of the reported difference in size of the perithecial bases in
C. laricicola and C. polonica isolates from Japan (25), we measured perithecial bases on MEA and other media, and measurements were made at $\times 200$ or $\times 400$.

Inoculations. Inoculations were preformed in the Krasnoyarsk Territory and Khakhassya (southern Siberia, Russia). Six trees of Picea obovata (Siberian spruce) and 12 trees of Larix sibirica (Siberian larch) of 25 to $30 \mathrm{~cm}$ diameter at breast height (dbh) were selected for inoculation. The $L$. sibirica trees were inoculated on 24 June 1998, and the P. obovata trees were inoculated on 29 June 1998. Three of the $P$. obovata trees were on a well-drained site, while three others were in a poorly drained area with excessive soil moisture. The $L$. sibirica trees had been subjected to natural defoliation by the Siberian moth (Dendrolimus superans sibiricus Tschetvr.). Three of the L. sibirica trees were not apparently defoliated, three of the trees had an estimated $50 \%$ foliage missing, three trees were $75 \%$ defoliated, and three trees were completely $(100 \%)$ defoliated at the time of inoculation.

Wounds were made in the stems in seven rings spaced at 80 to $200 \mathrm{~cm}$ height above the ground. Three wounds were evenly spaced around the circumference at each height, and the three wounds at each height were staggered with the wounds of adjacent heights. The wounds were made by a cork borer ( $8 \mathrm{~mm}$ diameter) to the depth of the cambium/xylem area. Inoculum consisted of mycelium and spores at the advancing margins of MEA grown isolates taken with the cork borer. On each tree, the three wounds of the top-most ring were not inoculated (controls), the next three lower rings were inoculated with $C$. polonica isolates pln24/96, C708, and C787, respectively, and the lowest three rings were inoculated with $C$. laricicola isolates 1r05/94, C746, and C178, respectively. The bark was removed 5 weeks after inoculation and the vertical extent (above and below the inoculation point) of necrosis in the cambium region was measured.

A three-way analysis of variance (ANOVA) was performed with host, fungal species, and stress as the variables (SAS Institute Inc., Cary, NC). For stress, the lesion size in the three $P$. obovata trees on the well-drained site was compared with that in the three trees on the poorly drained site, and the lesion size in the six L. sibirica trees with little defoliation ( 0 or $50 \%$ defoliation categories) was compared with the lesion size of the six $L$. siberica trees with 75 or $100 \%$ defoliation.

\section{RESULTS}

MAT-2 Sequences. Parsimony analysis of the aligned 197 characters from the DNA sequence of a portion of the MAT-2 HMG box determined that 48 characters were informative, 47 were parsimony uninformative, and 102 characters were constant. Two most parsimonious trees of 128 
steps were found, and the two trees differed only in the grouping of the three Japanese isolates of $C$. laricicola, which grouped as a single clade in the tree shown (Fig. 1), but the Japanese branch collapsed in polytomy with the other $C$. laricicola sequences in the other tree (not shown). The consistency index (CI) was 0.8359 (excluding uninfomative characters = 0.7237), the rescaled consistency index (RC) was 0.7503 , and the retention index (RI) was 0.8976. All C. polonica isolates had identical sequences, and there was strong bootstrap support for the clade The clade that included all the $C$. laricicola isolates also had strong support, though the Japanese isolates of $C$. laricicola differed slightly (5 bp) from the C. laricicola isolates from Europe and Russia (Fig. 1).

Interfertility. The isolates of $C$. laricicola from Scotland (MAT-1 isolate C178grouping the $C$. polonica isolates (Fig. 1).

38) and Russia (MAT-2 isolate C1285) were fully interfertile with each other (Table 1), producing perithecia with an abundance of normal ascospores with a high germination rate. Similarly, the $C$. polonica MAT-1 testers from Norway and Russia were fully compatible with MAT-2 isolates of C. polonica from Norway, Russia, and Japan. The progeny recovered from fully interfertile crosses between isolates of $C$. laricicola or between isolates of $C$. polonica segregated for colony morphology or, in the case of $\mathrm{C} 1226-3 \times \mathrm{C} 791-23$, the presence/absence of perithecial necks.

In 12 of 18 pairings between isolates of C. laricicola and C. polonica, no perithecia or only sterile perithecia (without ascospores) were found (Table 1). In the six other pairings between these species, perithecia with only small ascospore masses were seen, the droplet of spores was watery rather than the pink-opaque

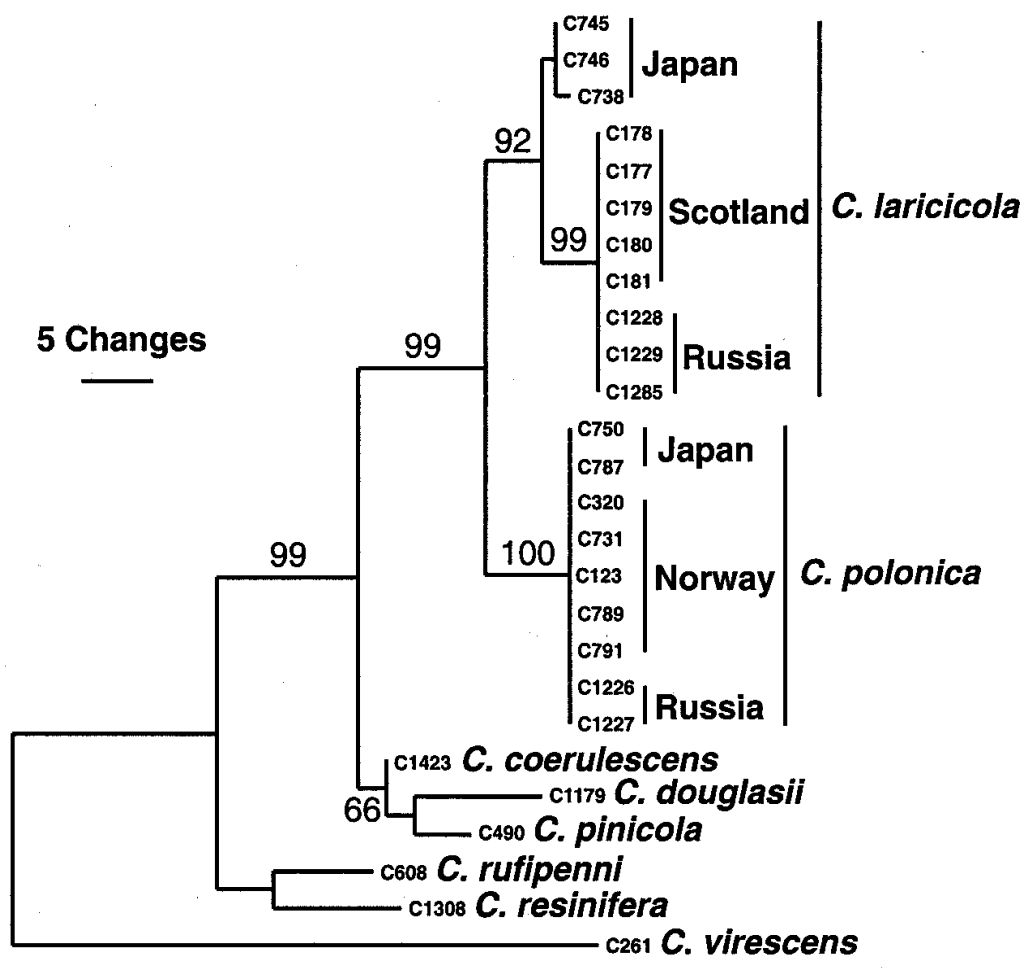

Fig. 1. One of two most parsimonius trees using a portion of the MAT-2 idiomorph of species in the Ceratocystis coerulescens complex. Bootstrap values greater than 50\% are indicated. spore mass formed from interfertile crosses, the ascospores were misshapen, and the ascospores did not germinate. This type of sexual incompatibility has been found in other interspecific pairings of Ceratocystis species (9).

Surprisingly, typical hybrid perithecia with misshapen ascospores of low germination rate were found in the intra-specific pairing of the Japanese MAT-2 isolate of C. lariciola and the Scottish MAT-1 isolate of $C$. laricicola. A few progeny were recovered from this latter cross, some of these isolates grew slowly, also typical of an interspecific hybrid (9), and the colony morphology of these progeny differed from that of either parent.

Morphology. Although the perithecial sizes varied greatly from isolate to isolate and even within a single petri plate, we did not see consistent differences among the media tested. We found that $C$. laricicola isolate C746 from Japan when grown on MEA had perithecial bases ranging from 280 to $352 \mu \mathrm{m}$ wide, similar to the range found in the C. laricicola isolate C179 from Scotland (272 to $380 \mu \mathrm{m}$ wide) and within the range of isolates of $C$. polonica from Europe and Russia (216 to $372 \mu \mathrm{m}$ wide). Mean width of perithecial bases for C. laricicola isolates C179 and C746 were 318 and $323 \mu \mathrm{m}$, respectively; while those from C. polonica isolates C708, C791, C732, C1226, and $\mathrm{C} 1227$ were 338, 302, 248,326 , and $290 \mu \mathrm{m}$, respectively.

Inoculations. Larger lesions were found in the $L$. sibirica trees inoculated with $C$. laricicola isolates than in the L. sibirca trees inoculated with $C$. polonica isolates, and the reverse was true in the $P$. obovata trees (Table 2). The ANOVA indicated that the host species, the source of the isolates (whether from Europe, Russia, or Japan), the fungal species, and the level of stress all contributed significantly to the variation (Table 3). In general, the L. sibirica trees with 75 or $100 \%$ defoliation had larger lesions than similarly inoculated trees with no or only $50 \%$ defoliation, and this trend was particularly evident with the trees inoculated with $C$. laricicola isolates (Table 2). Similarly, $P$. obovata trees on the poorly drained soil had larger lesions than

Table 1. Intraspecific and interspecific pairings among MAT-1 and MAT-2 strains of Ceratocystis laricicola and C. polonica

\begin{tabular}{|c|c|c|c|c|c|c|c|}
\hline & \multirow[b]{2}{*}{ Male/female } & \multicolumn{3}{|c|}{ C. laricicola, MAT-1 } & \multicolumn{3}{|c|}{ C. polonica, MAT-1 } \\
\hline & & C178-38, Scotland & Irc02-94, Russia & C745, Japan & C791-23, Norway & C1226-5, Russia & C755, Japan \\
\hline \multirow[t]{3}{*}{$\begin{array}{l}\text { C. laricicola, } \\
\text { MAT-2 }\end{array}$} & C178, Scotland & $\begin{array}{c}\text { Sterile } \\
\text { Perithecia }^{\mathrm{x}}\end{array}$ & $\ldots$ & $\ldots$ & Hybrid $^{w}$ & $\ldots$ & $\ldots$ \\
\hline & C1285, Russia & Interfertile $\mathrm{y}^{\mathrm{y}}$ & $\ldots$ & $\ldots$ & Hybrid $^{w}$ & Hybrid $^{w}$ & $\ldots$ \\
\hline & C738, Japan & Hybrid $^{\mathrm{z}}$ & $\ldots$ & $\ldots$ & Hybrid $^{\mathrm{w}}$ & & $\ldots$ \\
\hline \multirow[t]{3}{*}{$\begin{array}{l}\text { C. polonica, } \\
\text { MAT-2 }\end{array}$} & C320, Norway & $\begin{array}{c}\text { Sterile } \\
\text { Perithecia }\end{array}$ & $\ldots$ & $\ldots$ & Interfertile ${ }^{y}$ & Interfertile & $\cdots$ \\
\hline & C1226-3, Russia & Hybrid $^{w}$ & $\ldots$ & $\ldots$ & Interfertile ${ }^{y}$ & Interfertile ${ }^{y}$ & $\begin{array}{l}\cdots \\
\cdots\end{array}$ \\
\hline & C757, Japan & Hybrid $^{w}$ & $\ldots$ & $\ldots$ & Interfertile ${ }^{y}$ & Interfertile ${ }^{y}$ & $\ldots$ \\
\hline
\end{tabular}

\footnotetext{
${ }^{\mathrm{w}}$ Few perithecia and ascospores misshapened and mixed with debris. No viable progeny recovered.

${ }^{\mathrm{x}}$ Perithecia but no ascospores produced.

y Abundant perithecia and ascospores, and ascospores of high germination rate.

${ }^{\mathrm{z}}$ Few perithecia and some viable ascospore progeny with colony morphology differing from either parent.
} 
the trees on the better drained soil, and the difference was more pronounced with the $C$. polonica isolates than with the $C$. laricicola isolates. The largest source of variation in the ANOVA was host specialization of the fungal species, i.e., the host species $\times$ fungus species interaction term (Table 3). Because of this strong interaction, no statistical comparison of means was made.

\section{DISCUSSION}

The comparisons of DNA sequences of a portion of the MAT-2 idiomorph, intersterility, and physiological specialization to their respective hosts were consistent in distinguishing $C$. laricicola from $C$. polonica. The fixed difference in the electromorphs for diaphorase (11) also supported the distinction between these two species. The lack of difference in ITS sequences (24) and the morphological similarity of the two species suggest that they are very recently diverged, and host adaptation may have been the driving force in speciation.

In addition to the pairings reported here and in an earlier study (9), we have made many other attempts to cross isolates of $C$. polonica and $C$. laricicola, but these pairings have failed to produce perithecia and ascospores, or the ascospores produced were indicative of an incompatible cross between two species. In the earlier study (9), a small number of perithecia with small ascospore masses were seen in the pairing of isolates C123 (C. polonica, MAT-2) and C178-38 (C. laricicola, MAT1 ), and the few viable progeny recovered had very slow growth and produced few perithecia. In the present study, we were unable to obtain viable progeny from the six interspecific hybrid pairings in which ascospores were produced.

Fully interfertile crosses were seen in intraspecific pairings between isolates of $C$. laricicola from Russian and European isolates, but not in intraspecific pairings of Japanese isolates of $C$. laricicola with European or Russian isolates. Our Japanese isolates of $C$. polonica and C. laricicola have lost their fertility (the MAT-2 isolates no longer produce perithecia through selfings), and the MAT-1 isolates from Japan failed to produce perithecia or ascospores when paired with MAT-2 iso- lates. No perithecia were formed in the MAT-1 $\times$ MAT-2 cross of the Japanese $C$. laricicola testers, perhaps because $\mathrm{C} 755$ is a self-sterile MAT-2 isolate and not a MAT-1 isolate, as presumed. Because of this ambiguity, it is questionable if the Japanese isolates of $C$. laricicola are truly incompatible with European and Russian isolates of this species. However, the Japanese isolates of $C$. laricicola had MAT-2 sequences that differed slightly from those of C. laricicola isolates from Europe and Russia. Thus, there is some indication that C. laricocola from Japan is distinct from the $C$. laricicola found in Russia and Europe.

We have been unable to distinguish these two species morphologically, but Yamoaka et al. (25) reported that Japanese isolates of $C$. laricicola have perithecial bases that are 145 to $300 \mu \mathrm{m}$ wide, while C. polonica isolates from Japan had perithecial bases 200 to $390 \mu \mathrm{m}$ wide. However, under our conditions, $C$. laricicola isolate C746 from Japan had perithecial bases ranging from 280 to $352 \mu \mathrm{m}$ wide, similar to those of other $C$. laricicola isolates and to isolates of $C$. polonica. Unfortunately, our $C$. polonica isolates from Japan no longer produce perithecia, but the measurements provided by Yamaoka et al. (25) are consistent with those of our European and Russian isolates of $C$. polonica and $C$. laricicola. In general, sizes of perithecial bases and necks vary greatly within and among Ceratocystis species (12), and it has been difficult to distinguish closely related species by such features. With respect to evolutionary pressure, the size of perithecia may not be significant in the respective ecological niches of these two species as their respec- tive vectors, Ips cembrae and I. typographus, do not differ substantially in the types of galleries they construct nor in the size of the adult beetles, the stage at which ascospores are acquired.

Perhaps the most important phenotypic character separating $C$. laricicola from $C$. polonica is the degree of aggressiveness to their respective plant hosts. Using standard inoculation methods and lesion size to assess aggressiveness $(2,13,14,16,18,25,26)$, our inoculation data showed clearly that $C$. laricicola and $C$. polonica cause larger lesions sizes in their respective hosts than in their nonhosts. Trees stressed by insect defoliation or poorly drained soil showed greater lesion size than their unstressed counterparts. The host specialization found here further supports the contention that the pathogenicity of these fungi is ecologically significant, and that these fungi may be an important aid to their respective bark beetle vectors in killing trees (15).

Although the two fungal species are sympatric across Eurasia and are morphologically identical, the MAT-2 sequences clearly indicate that they belong to separate lineages. Interfertility barriers appear to have maintained these separate lineages, lineages that were not recognized by ITS sequencing (23). In spite of our inability to distinguish these MAT-2 lineages by morphology, the evidence presented here supports maintaining them as distinct species (12) and supports the assertion that physiological characters such as host specialization should be sufficient to delineate monophyletic lineages as species (10).

\section{ACKNOWLEDGMENTS}

Funded in part by a grant from the USDA/FAS/ICD/Research and Scientific Exchanges (Agreement No. 58-3148-6-019) and the

Table 3. Three-way analysis of variance of lesion length in Larix sibirica and Picea obovata inoculated with Ceratocystis laricicola and C. polonica

\begin{tabular}{lcccc}
\hline Source of variation & df & Mean square & $\boldsymbol{F}$ value & $\boldsymbol{P}>\boldsymbol{F}$ \\
\hline L. sibirica vs. $P$. obovata & 1 & 126,365 & 34.10 & $<0.0001$ \\
Stressed vs. healthy trees & 1 & 193,891 & 52.33 & $<0.0001$ \\
C. laricicola vs. C. polonica & 1 & 115,387 & 31.14 & $<0.0001$ \\
European vs. Russian vs. Japanese isolates & 2 & 94,931 & 25.62 & $<0.0001$ \\
Host species $\times$ stress & 1 & 120,077 & 32.41 & $<0.0001$ \\
Host species $\times$ stress $\times$ fungus species & 2 & 207,169 & 55.91 & $<0.0001$ \\
Host species $\times$ fungus species & 1 & 309,903 & 83.64 & $<0.0001$ \\
Error & 314 & 3,705 & & \\
\hline
\end{tabular}

Table 2. Extent of lesions (mean \pm standard error of 9 measurements, in $\mathrm{mm}$ ) in trees of Larix sibirica and Picea obovata inoculated with Ceratocystis laricicola or C. polonica

\begin{tabular}{|c|c|c|c|c|c|c|c|}
\hline \multirow[b]{3}{*}{ Fungal species } & \multirow[b]{3}{*}{ Isolate no. } & \multirow{2}{*}{\multicolumn{4}{|c|}{ Larix sibirica }} & \multicolumn{2}{|c|}{ Picea obovata } \\
\hline & & & & & & \multirow[b]{2}{*}{ Healthy trees } & \multirow{2}{*}{$\begin{array}{c}\text { Poorly } \\
\text { drained site }\end{array}$} \\
\hline & & No defoliation & $50 \%$ defoliation & $75 \%$ defoliation & $100 \%$ defoliation & & \\
\hline \multirow[t]{3}{*}{ C. laricicola } & $\mathrm{C} 178$ & $26.8 \pm 1.2$ & $41.0 \pm 3.8$ & $41.4 \pm 3.2$ & $43.0 \pm 2.0$ & $21.1 \pm 1.0$ & $20.8 \pm 2.3$ \\
\hline & $\operatorname{lrc} 05 / 94$ & $40.0 \pm 4.4$ & $45.4 \pm 3.4$ & $210.2 \pm 32.2$ & $327.4 \pm 65.0$ & $20.1 \pm 1.5$ & $24.2 \pm 1.2$ \\
\hline & $\mathrm{C} 746$ & $39.3 \pm 2.7$ & $40.8 \pm 6.0$ & $252.0 \pm 105.8$ & $439.9 \pm 19.9$ & $19.6 \pm 2.4$ & $22.9 \pm 3.5$ \\
\hline \multirow[t]{3}{*}{ C. polonica } & C708 & $20.8 \pm 1.3$ & $19.1 \pm 2.6$ & $23.7 \pm 2.7$ & $24.3 \pm 2.6$ & $21.9 \pm 3.5$ & $42.8 \pm 5.2$ \\
\hline & pln24/96 & $18.3 \pm 1.9$ & $22.2 \pm 7.4$ & $26.4 \pm 2.7$ & $21.6 \pm 1.9$ & $42.9 \pm 4.8$ & $62.9 \pm 5.5$ \\
\hline & C787 & $22.1 \pm 1.7$ & $21.2 \pm 3.1$ & $27.2 \pm 2.3$ & $32.7 \pm 1.9$ & $46.7 \pm 2.6$ & $65.0 \pm 10.8$ \\
\hline Control & & $10.8 \pm 1.1$ & $17.3 \pm 2.2$ & $19.7 \pm 1.6$ & $17.3 \pm 3.3$ & $10.2 \pm 1.0$ & $10.2 \pm 0.9$ \\
\hline
\end{tabular}


National Science Foundation (DEB-9870675). We thank Y. Yamaoka, M. Wingfield, D. Redfern, and H. Solheim (The Norwegian Forest Research Institute) for supplying cultures. Journal Paper No. J-19385 of the Iowa Agriculture and Home Economics Experiment Station, Ames, IA, Project No. 3226, and supported by Hatch Act and State of Iowa funds.

\section{LITERATURE CITED}

1. Arie, T., Christiansen, S. K., Yoder, O. C, Turgeon, B. G. 1997. Efficient cloning of ascomycete mating type genes by PCR amplification of the conserved MAT HMG Box. Fungal Genet. Biol. 21:118-130.

2. Christiansen, E., Solheim, H. 1990. The bark beetle-associated blue-stain fungus Ophiostoma polonicum can kill various spruces and Douglas fir. Eur. J. For. Pathol. 20:436-446.

3. DeScenzo, R. A., Harrington, T. C. 1994. Use of $(\mathrm{CAT})_{5}$ as a DNA fingerprinting probe for fungi. Phytopathology 84:534-540.

4. Felsenstein, J. 1985. Confidence limits on phylogenies: an approach using the bootstrap. Evolution 39:783-791.

5. Harrington, T. C. 1988. Leptographium species, their distribution, hosts, and insect vectors. Pages 1-39 in: Leptographium Root Diseases on Conifers. T. C. Harrington and F. W. Cobb, Jr., eds. American Phytopathological Society, St. Paul, MN.

6. Harrington, T. C. 1993. Biology and taxonomy of fungi associated with bark beetles. Pages 37-58 in: Beetle-Pathogen Interactions in Conifer Forests. T. D. Schowalter and G. M. Filip, eds. Academic Press, San Diego.

7. Harrington, T. C. 1993. Diseases of conifers caused by Ophiostoma and Leptographium. Pages 161-172 in: Ceratocystis and Ophiostoma, Taxonomy, Ecology and Pathogenicity. M. J. Wingfield, K. A. Seifert, and J. F. Webber, eds. American Phytopathological Society, St. Paul, MN.
8. Harrington, T. C., and McNew, D. L. 1997. Self-fertility and uni-directional mating type switching in Ceratocystis coerulescens, a filamentous ascomycete. Current Genet. 32:5259.

9. Harrington, T. C., and McNew, D. L. 1998. Partial interfertility among the Ceratocystis species on conifers. Fung. Genet. Biol. 25:4453.

10. Harrington, T. C., and Rizzo, D. M. 1999. Defining species in the fungi. Pages 43-71 in: Structure and Dynamics of Fungal Populations. J. J. Worrall, ed., Kluwer Press. Dordrecht, the Netherlands.

11. Harrington, T. C., Steimel, J., Wingfield, M. J., and Kile, G. A. 1996. Isozyme variation and species delimitation in the Ceratocystis coerulescens complex. Mycologia 88:104113.

12. Harrington, T. C., and Wingfield, M. J. 1998. The Ceratocystis species on conifers. Can. J. Bot. 76:1446-1457.

13. Kirisitis, T. 1998. Pathogenicity of three bluestain fungi associated with the bark beetle Ips typographus to Norway spruce in Austria. Oesterr. Z. Pilzk. 7:191-201.

14. Krokene, P., and Solheim, H. 1998. Pathogenicity of four blue-stain fungi associated with aggressive and nonaggressive bark beetles. Phytopathology 88:39-44.

15. Paine, T. D., Raffa, K. F., and Harrington, T. C. 1997. Interactions among scolytid bark beetles, their associated fungi, and live host conifers. Annu. Rev. Entomol. 42:179-206.

16. Redfern, D. B., Stoakley, J. T., Steele, H., and Minter, D. W. 1987. Dieback and death of larch caused by Ceratocystis laricicola sp. nov. following attack by Ips cembrae. Plant Pathol. 36:467-480.

17. Siemaszko, W. 1939. Zespoly grzybow towarzyszacych kornikom polskim. Planta Pol. 7:1-52.

18. Solheim, H. 1993. Fungi associated with the spruce bark beetle Ips typographus in an endemic area in Norway. Scand. J. For. Res. 8:118-122.

19. Swofford, D. L. 2001. PAUP*. Phylogenetic Analysis Using Parsimony (*and Other Methods). Version 4. Sinauer Associates, Sunderland, Massachusetts.

20. Visser, C., Wingfield, M. J., Wingfield, B. D., and Yamaoka, Y. 1995. Ophiostoma polonicum is a species of Ceratocystis sensu stricto. Syst. Appl. Microbiol. 18:403-409.

21. Wingfield, M. J., Harrington, T. C., and Solheim, H. 1997. Two species in the Ceratocystis coerulescens complex from conifers in western North America. Can. J. Bot. 75:827834.

22. Witthuhn, R. C., Harrington, T. C., Steimel, J. P., Wingfield, B. D., and Wingfield, M. J. 2000. Comparison of isozymes, rDNA space regions, and MAT-2 DNA sequences as phylogenetic characters in the analysis of the Ceratocystis coerulescens complex. Mycologia 92:447-452.

23. Witthuhn, R. C., Harrington, T. C., Wingfield, B. D., Steimel, J., and Wingfield, M. J. 2000 Deletion of the MAT-2 mating type gene during uni-directional mating type switching in Ceratocystis. Curr. Genet. 38:48-52.

24. Witthuhn, R. C., Wingfield, B. D., Wingfield, M. J., Wolfaardt, M., and Harrington, T. C. 1998. Monophyly of the conifer species in the Ceratocystis coerulescens complex using DNA sequence data. Mycologia 90:96-100.

25. Yamaoka, Y., Wingfield, M. J., Ohsawa, M and Kuroda, Y. 1998. Ophiostomatoid fungi associated with Ips cembrae in Japan and their pathogenicity to Japanese larch. Mycoscience 39:367-378.

26. Yamaoka, Y., Wingfield, M. J., Takahashi, I., and Solheim, H. 1997. Ophiostomatoid fung associated with the spruce bark beetle Ips typographus f. japonicus in Japan. Mycol. Res. 101:1215-1227. 